\title{
CONTINUITY AND CHANGE IN TURKISH FOREIGN POLICY DURING THE JDP GOVERNMENTS
}

Justice and Development Party's (JDP's) foreign policy which has been formulated by Ahmet Davutoğlu can be described as an eclectic and pragmatic foreign policy of a "trading state" with some ideological and rhetorical colours. This policy at discursive level refers to the glorious Ottoman past, religious and cultural linkages of Turkey with the Muslim world and the ex-Ottoman geography spanning from North Africa to Middle East and to the Balkans. ${ }^{2}$ It describes Africa, Asia and Latin America as new fields of interest. At practical level, this policy is based on a close cooperation with the global hegemon US. It was aggressively targeting the EU membership but later lowered down its temper mostly due to the reluctance of the EU side and de facto impracticability and un-sustainability of working for a quick membership. Establishing and developing good relations with Russia has also been targeted with this policy. This policy is also based on a rhetorical criticism of the foreign policies of previous Turkish governments with dogmatism and western oriented ideological blindness.

The last half of the second term of JDP government has witnessed a heated debate on axis change in Turkish foreign policy. ${ }^{3}$ Israel's attack on Gaza Strip in December 2008 while Turkish government was intermediating for a peace between Israel and Syria; Prime Minister Erdoğan's corresponding "one minute" reaction to Israeli president Simon Perez; Israel's attack on Mavi Marmara ship which was carrying humanitarian aid to Gaza strip that was subject to an Israeli blockade and Israel's disproportional use of power which caused the killing of 9 Turkish citizens; Turkey's

\footnotetext{
1 "Trading state" is a term that Kemal Kirişçi introduced and used to name new Turkish foreign policy (Kirişçi, 2009).

2 Davutoğlu's foreign policy, even though he rejects such claims, is frequently identified as pan Ottomanist. For a concise account of the term neo-Ottomanism, pls. see Mustafa Şahin (2011). In this article Şahin identifies JDP policies as neo-Ottomanist. He also explains why Davutoğlu refrains using this term by referring to Kemal Karpat who claimed that the term first used by Greeks after Turkey landed its forces to Cyprus in 1974. So it is these negative connotations regarding the perception of the Turks in ex-Ottoman territories why JDP does reject this naming.

3 Some of the Turkish columnists and scholars who refer to this debate are, Mensur Akgün (2009), Mehmet Ali Birand (2010), Cengiz Çandar (2000), Yalım Eralp (2010), Tarık Oğuzlu (2008). It is also important to note that most of the Turkish scholars who are talking about this axis shift on Turkish foreign policy are either very shy or careful about their claims. The careful ones mostly refer to the claims on axis shift made by others and try to analyze this question with care. It is mostly the non-Turkish scholars who claimed that there exists a tangible shift/change on TFP. Among these, Thomas Friedman (2010), Mark Steyn (2010), Dominique Moisi (2009), Efraim Inbar (2011) can be referred.
} 
no vote on the UN Security Council resolution to impose additional sanctions to Iran and Turkey's Syria policy which was not following the tough policies that US was following and proposing for Turkey, have been the important indicators and turning points for this claimed change.

However, together with the start of Arab Spring, US's evacuation of Iraq and Turkey's permission to NATO to launch an anti-missile system in Malatya; Turkey's angry reaction to Syrian government against their repressive actions on the sectarian conflict in this country, another debate which emphazises a return on Turkish policy to the traditional western oriented diplomacy started.

Among these events US's evacuation of Iraq has a critical effect over the course of events. It was expected by the regional actors that this withdrawal would create a power vacuum in Iraq. So actors which have an interest over the region acted more swiftly to take the advantage in this country. This led to an increase in the visibility of the undercurrent on going conflicts mainly between Iran and Turkey. Pace of events increased more with the Arab spring. Then it became impossible for regional actors to settle disputes slowly and keep them under their control. The size of the crises and the arguments of the uprising groups also made it difficult for Turkish government to develop a consistent foreign policy.

This article aims to go behind the debate on the change in Turkish foreign policy at rhetorical level. It also critically analyses the arguments which claim that Turkey returned back to its original foreign policy stance. It basically claims that there has been a deep on going material change on the social and economic bases of Turkish foreign policy for last 30 years. What $J D P$ basically did was reading this change truly and conveying it to the political level through a populist rhetoric and populist policies. This populist policy addressed the political needs that already existed at societal and economic level and tried to convert this need on foreign policy field to the votes of Turkish citizens for last three elections.

The article will first examine Davutoğlu's theoretical perspective which frames this change and lead both the change and its actors. Then, increasing international commercial and economic activities of Turkish businessman; increasing cultural interactions and lastly increasing human mobility will be analysed. What is new on Davutoğlu's foreign policy formulations; whether there is a change in the direction of foreign trade and international investments; whether there exists a new dynamism in the cultural interactions field and whether there exist a change in Turkish citizens' mobility are some of the basic questions that will be answered in this article. These questions and their answers will be linked to the change in Turkish foreign policy debate in the concluding section.

\section{FOREIGN POLICY PERCEPTION OF THE JDP: FOREIGN MINISTER AHMET DAVUTOĞLU'S THEORETICAL APPROACH}

From the beginning $J D P$ leadership trusted Ahmet Davutoğlu on its foreign policy formulations and operations. Davutoğlu's influence is mainly due to the former Foreign Minister and current president Abdullah Gül and Prime Minister Erdoğan's will to adopt Davutoğlu's vision to Turkish Foreign Policy's implementation (Aras, 2009: 3) 
as it just fits to their political ideology. An academic by origin, Ahmet Davutoğlu had tried to apply his academic studies and works to Turkey's current foreign policy stance and policy projections for the future. Davutoğlu, during the early period of his alignment with the $J D P$ preferred to stay away from the public's eyes and tried to guide $J D P$ 's foreign policy as an advisor to the Prime Minister. He had been known as the head/master architect of Turkish Foreign Policy in between 2002 and May 2009. By May 2009, he became the Minister of Foreign Affairs of Turkey.

The roots/clues of Foreign Minister Davutoğlu's understanding regarding Turkish Foreign Policy can be seen in his book titled, the Strategic Depth (2009). The book makes a comprehensive critique of Turkish Foreign policy since the Ottoman period. This critique is made through a strategy discipline perspective. After presenting the basic principles of frequently referred strategic thinking, Davutoğlu draws some conclusions and gives some prescriptions for an effective and influential implementation of Turkish foreign policy, in this book. ${ }^{4}$

For Davutoğlu strategic thinking is very crucial for the formulation and implementation of an effective FP. For him geography and time dimensions are the two factors that are very important to have a deep insight and understanding about the processes that countries are in (Davutoğlu, 2010: 6). Turkey has geographic advantages and very valuable historical luggage/assets that she should be considered. During the Cold War period Turkey had tried to utilize this geographical luggage in a very static manner and did not intentionally referred to cultural and historical assets (ibidem: 116). However the geography did not provide the expected advantages, as history, ${ }^{5}$ strategic thinking and political will dimensions were lacking.

Davutoğlu grounds his strategic mentality concept to history but at the same time the strategic planning that he refers to is based on the realities of the day. So Davutoglu basically tries to combine this strategic mentality with the strategic planning (ibidem: 61). This way of thinking makes history and culture dynamic and useful tools to develop a foreign policy for today's needs without making history and culture a static and costly liability.

Davutoğlu puts a mathematical formula which shows the determinants of power that he frequently refers in his book. This formula speaks for itself. It is: $\mathrm{P}=(\mathrm{CV}+\mathrm{PV})$ $\times(\mathrm{SI} \times \mathrm{SP} \times \mathrm{PW}){ }^{6}$

4 Davutoğlu was criticized from within his party by a member of party's governing board as he was conducting Turkish Foreign Policy according to his book and as he was promoting his person. Davutoğlu responded to these claims that the book was written in an earlier time and some parts would be older as well as the conditions and he was not conducting the foreign policy according to the book. He also stated that Foreign policy was determined by taking into consideration developments and Turkey's interests under the direction of Prime Minister Erdogan and the claim which was stating that he was bringing himself forward was out of question ("Milliyet", 2010).

5 Davutoğlu charges Turkish intellectuals as they cut the linkages with the Ottoman and Seljuk Empire periods on their thoughts and writings (Davutoğlu, 2010: 407).

${ }_{6}$ In this formula SM refers to Strategic Mentality; SP refers to Strategic Planning and PW refers to Political Will, CV refers to Constant Variables and it is basically comprised of history (h), geography (g), population (p) and culture (c); PV refers to Potential Variables and it comprises of economic potential (ep), technological capacity (tc) and military capacity $(\mathrm{mc})$. The expanded form of this formula is: $\mathrm{P}=[(\mathrm{h}+\mathrm{g}+\mathrm{p}+\mathrm{c}) \times(\mathrm{ep}+\mathrm{tc}+\mathrm{mc})] \times(\mathrm{SM} \times \mathrm{SP} \times \mathrm{PW})$. See: Davutoğlu (2010: 17). 
This formula basically says that a country's or political actors' power is related with their history, geography, population and culture plus that country's economic, technological and military capacity. However cumulating these factors is not sufficient to show a country's power. These assets only after furnished, supported by a strategic mentality, strategic planning and political will, will make a multiplier effect and would create a boost and make country more powerful.

This formula with its first part, basically, configures the traditional understanding of conservative thinkers and political parties in Turkey. So, reference to geography, population, culture and specifically to Ottoman past is not new. ${ }^{7}$ What is new in this formulation is the stress to strategic mentality, strategic planning and political will and the boosting effect of all of them. Davutoğlu claims that all the factors in the first part, could have a meaning and a real impact only after the inclusion or implementation of the second part of the formula. Turkey has already had the first part and it is very rich compared to other countries in this field. However the second part was missing and $J D P$ has basically tried to fill this second part by adopting a strategic mentality, and strategic planning manner backed by a strong political will. JDP's long and stable single party government period also helped to the effective implementation of this mentality and planning.

Focus on strategic mentality leads to a change in the perception of economy and culture. $J D P$ governments, in line with the first part of formula, engaged in activities to create new incentives for Turkey's business community on international trade. This was an already existing pattern since 1983 . What $J D P$ added to this pattern was the strategic mentality. This policy was also fed from the demands of newly rising classes that were in close contact with the ruling party. On the social level, mostly with the demands and incentives of economic agents, cultural encounters, starting with neighbours and important markets, increased. High level trade missions headed by Prime Minister or the President mostly concluded with bilateral agreements to facilitate trade and cultural interaction. These agreements provided free trade opportunities, cultural interaction and a free travel regime in the region.

On the remaining parts of this article some structural/paternal changes on some decisive areas of Turkish politics and economy as well as social life will be examined.

\section{CHANGE IN TURKEY'S FOREIGN TRADE AND SERVICES}

The activities of Turkish traders have increasingly influenced the decisions and stance of Turkish governments during the last 30 years. Since the January 24 Decisions (1980), Turkey has been following export promotion policy instead of previous period's import promotion policies. This policy created a very important dynamism in Turkish economy, politics and society. The agents of this policy, big, medium and small size industrialists, and traders started to search for new markets to sell their products.

7 Among the conservative scholars reference to Ottoman legacy, and being inspired by this, is observed in different degrees. Among these scholars one can count Osman Turan (1969), Y1lmaz Öztuna (1998), Yahya Kemal (1975), Samiha Ayverdi (1975-76), Mehmet Kaplan (1967). 
Once they exploited their immediate destinations and faced competition with the traders from other nations they looked for other markets. So starting from the most secure guaranteed markets to least secure and risky markets, traders from different strata's of society and parts of economy, run for access to and possession of new markets.

The Customs Union with the EU was one of the most important developments in this process. Customs Union opened up European markets to Turkish producers and traders and they benefited from these regular and easy to operate markets. Turkish economy at this moment seems highly dependent to the European markets. However as Turkey is not within the Union as a full member and as she does not have a say over the political decisions which direct the European trade, European market is too much out of control. So for instance Brussels has concluded free trade agreements with Mexico and South Korea. This fact already disturbed the profit margins of Turkish traders as those new countries are also provided with an access to the EU market in return for some gains for the Europeans. ${ }^{8}$ As European market is too competitive profit margins are already low for Turkey's not so high tech industries.

Turkish government's policy of keeping the exchange value of Turkish lira relatively high $v i s-\grave{a}$-vis the other currencies also forced Turkish traders to search for new markets in which they would have less competition and higher profit margins. Russia, Central Asia, Balkans have been the first markets that Turkey's traders and service providers tried to gain. Geographical proximity, family connections, language skills and cultural and/or religious closeness helped Turkish businessman in this process.

As it was mentioned above, $J D P$ government adopted a strategic mentality perspective to foreign trade as well. This facilitated the already existing interest of Turkish traders for neighbouring markets and markets of countries with similar cultural and religious background. These new market areas have been considered as natural extension that Turkey should work with. Once the commercial relations started, the process became mutually constitutive. Businessman asked for better relations with these commercially fertile markets. The $J D P$ governments saw these markets and developing good relations with their governments, not as a burden but as an asset for Turkey. It is not easy to say which started first; traditionally it is quite difficult to have good commercial relations before government gave a green light. But if there is no big problem and things to lose, it is easier for government to give this green light as it perceives developing trade as employment and tax generator at least. However, as it is the case with Iran and Armenia, even though there are ready agents to initiate business, the trade potential cannot be utilized effectively due to the political barriers.

When examined in a time frame, the changing patterns of Turkey's foreign trade become highly visible, during the $J D P$ governments. Turkey's export performance shows a steady increase between 2001 and 2011 except a contraction which existed due to the

8 The countries which signed a free trade agreement cannot be forced to sign the similar agreements with Turkey. Therefore, they can sell their products to Turkey without customs duties; however Turkish traders should pay a customs duty when they export their products to those countries. As the EU has been signing such free trade agreements with other countries (negotiations with Russia, India and Canada are continuing) and as those countries avoid signing such agreements bilaterally with Turkey, the advantages that the Customs Union Agreement created for Turkish industrialists are diminishing ("Cumhuriyet", 2010). 
global economic crises in 2009. The actual growth of Turkey's total exports reached to $331 \%$ by the end of 2011 since 2001 . Even though it is still the number one export destination, there is a net 10 points decline on the share of the European Union in Turkey's exports in this period. There exists an 11 points increase in Turkey's export to the Near and the Middle East and it reached $21 \%$ by 2011 from a 10\% of 2001.

Fig. 1. Turkey's Foreign Trade

\section{Exports 2011}

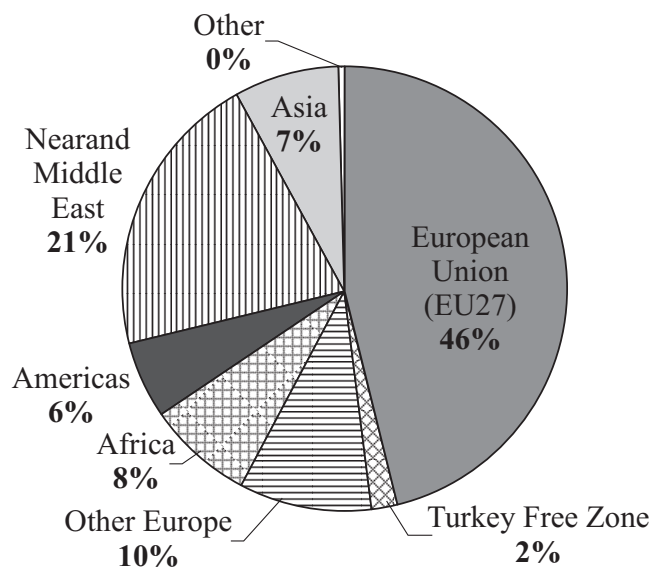

Export 2001

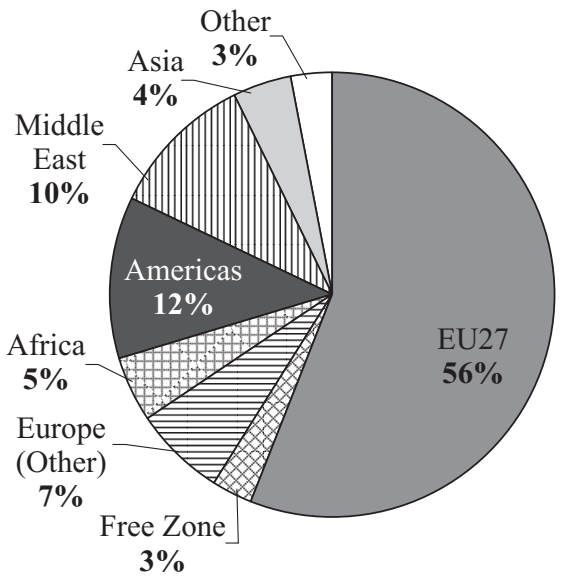

Source: Turkish Statistical Institute (TUIK), http://www.tuik.gov.tr, 19.05.2013.

An examination of Turkey's export performance by country groups particularly shows us that there is a very big increase on Turkey's exports to the Organization of Islamic Conference countries, Economic Cooperation Organization, Organization of Black Sea Economic Cooperation countries and Commonwealth of Independent States members both in percentage and volume in the same time period.

Turkey's export by country groups

\begin{tabular}{|c|c|c|c|c|c|c|}
\hline \multirow{2}{*}{$\begin{array}{c}\text { Foreign Trade by Selected } \\
\text { Country Groups }\end{array}$} & \multicolumn{3}{|c|}{ Export } & \multicolumn{3}{|c|}{ Import } \\
\hline & 2011 & 2001 & change & 2011 & 2001 & change \\
\hline OECD & $67,114,103$ & $21,307,462$ & $215 \%$ & $121,327,633$ & $26,885,976$ & $351 \%$ \\
\hline EFTA & & 316,114 & $497 \%$ & $5,845,715$ & $1,480,929$ & $295 \%$ \\
\hline Black Sea Economic Cooperation & $17,767,964$ & $2,932,471$ & $506 \%$ & & $5,553,206$ & $598 \%$ \\
\hline Economic Cooperation Organization & $9,291,736$ & 971,620 & $856 \%$ & $17,305,837$ & $1,237,671$ & $1298 \%$ \\
\hline Commonwealth of Independent States & $13,376,636$ & $1,978,150$ & $576 \%$ & $33,159,185$ & $4,630,241$ & $616 \%$ \\
\hline Turkic Republics & $5,039,884$ & 557,362 & $804 \%$ & $3,642,096$ & 282,509 & $1189 \%$ \\
\hline Organization of Islamic Conference & $37,325,453$ & $4,196,595$ & $789 \%$ & $31,417,772$ & $5,539,877$ & $467 \%$ \\
\hline
\end{tabular}

Source: Turkish Statistical Institute (TUIK), http://www.tuik.gov.tr, 19.05.2013.

When Turkey's import figures examined in the same time frame it is seen that the European Union is still the biggest provider for Turkey. However the EU's share shows 
a 10 point decline and share of Asia (China, India etc.) increases 10 points in the same period. Economic Cooperation Organization, Turkic Republics, Organization of Black Sea Economic Cooperation, Commonwealth of Independent States and Organization of Islamic Conference member countries are other important providers which constantly increased their shares in Turkish economy in the same order.

Fig. 2. Turkey's import
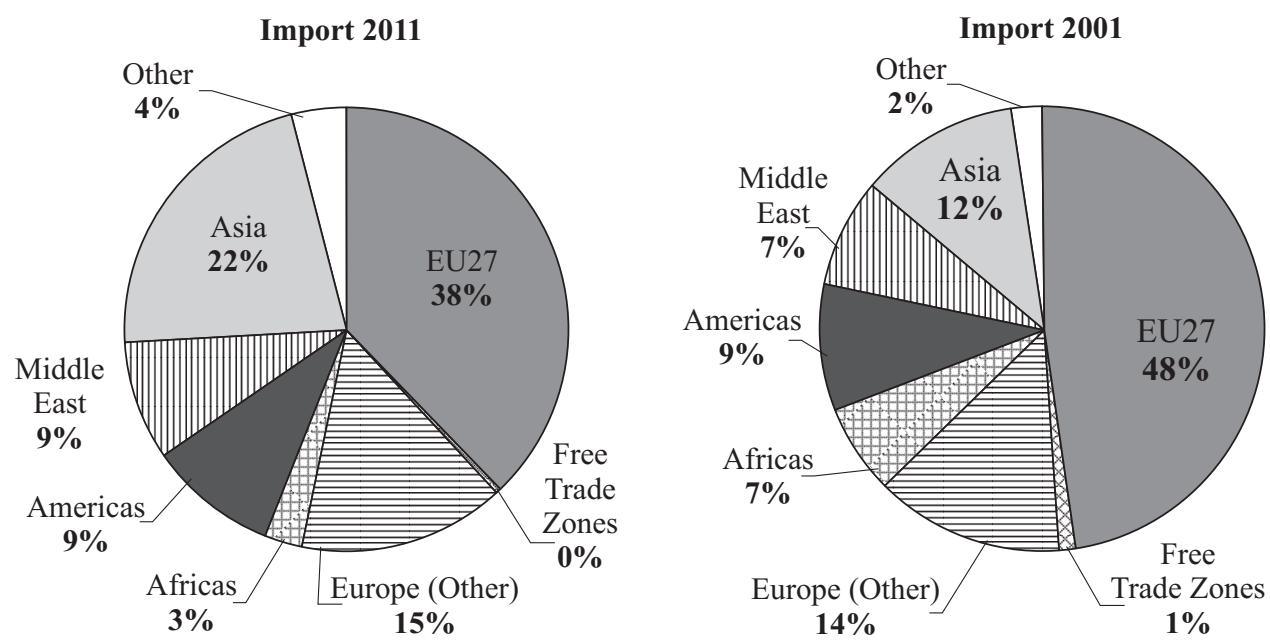

Source: Turkish Statistical Institute (TUIK), http://www.tuik.gov.tr, 19.05.2013.

There is also a steady increase in the performance of Turkey's construction companies' services abroad. In this field Commonwealth of Independent States, Middle East and African Countries are the first three regions in which Turkish construction companies made business most between 2004 and $2010 .^{9}$

Arab spring made a temporary impact on Turkey's export and construction services. Free trade agreement with Syria is annulled, Libya is in turmoil and construction companies are influenced from this fact. However, after a probable democratic settlement, relations would be expected to go deeper, Turkey and her business agents would take more shares over these countries' economies.

\section{EXPORT OF CULTURAL PRODUCTS AND CHANGING TOURIST COMPOSITION}

The visible dynamism at the culture industry has its impact on the perceived change on Turkish Foreign Policy as well. The activity in this field, create an impact over the audiences and readers of the countries which consume Turkish cultural products. Turkey becomes a country that the public in those countries follow. The interaction among Turkey and those countries remarkably increases and let to a ramification.

9 http://www.dtm.gov.tr/dtmadmin/upload/ANL/YurtDisiMuteahhitDB/.../sektor.doc, 19.02.2011. 
According to $U N D P$ statistics, Turkey has been the second fastest growing economy after India by $18.3 \%$ growth rate on art industry. Turkey's estimated total foreign trade on movies, music and literature is about USD 528 million with USD 408 million exports and USD 120 million imports.

The export volume of copyrights for translations from Turkish is about USD 400 million per year and reached to USD 2 billion within last 5 years ("Zaman", 2010). Ministry of Culture has been conducting a project named TEDA for promotion of translation and publishing of Turkish cultural products abroad. According to this project 151 books were translated and published in Germany, 93 books in Bulgaria, 46 books in Iran, 41 books in the US, 38 books in Egypt, 32 books in France, 30 books in Macedonia, 29 books in Greece, 28 in Bosnia Herzegovina, 25 in Russia since 2005. The total volume of published books within this Project has reached to 893 by February 2013. ${ }^{10}$

There has been a steady increase in the export of Turkish TV dramas since 2006, too. Central Asian, Arabic, Central European and Balkan countries are the main buyers of these dramas. More than 70 "made in Turkey" TV dramas exported to more than 20 different countries and reached to a volume of 50 million USD by the end of year $2010 .^{11}$

Especially the export of TV dramas has been very influential over the development of a positive image of Turkey in her region. A research conducted by Turkish Economic and Social Studies Foundation (TESEV) shows that $78 \%$ of the interviewees have at least once in their lifetime watch a Turkey made TV drama. This ratio is highest in Iraq by $89 \%$ and in Syria by 85 per cents. These dramas are very popular in the Arab world and interviewees can name 15 Turkish dramas and artists region wide when they are asked. Popularity of these dramas have its impacts over Turkeys export performance and incoming tourism industry. The stars of these dramas are used in the advertisement of Turkish consumer products in the Middle East. There are plans to install Turkey made consumer products into these TV dramas to be able to make indirect advertisement of them. TV dramas also promoted Turkey's tourism. People from all Arab world and Balkans come to Turkey to visit the locations that those TV dramas are shot (Mensur Akgün et al., 2010: 15-16; Buttler, 2009).

However, there are also some resistance and critiques to exported Turkish cultural products, especially Turkish TV dramas. The conservative political groups that rose to power during the Arab spring are quite critical of these TV dramas. They found these dramas dangerous for the moral and religious values of their traditional societies. There is a tendency for censorship among those countries. However those dramas are still the mostly viewed ones today and lead to an increase in tourist numbers from Middle East to Turkey.

Increasing tourist interest to Turkey is not only related with the TV dramas. In between 2003 and 2009 the number of tourists that visited Turkey increased 90\% and

10 Total number of books translated from Turkish to other languages since the foundation of the republic does not exceed 500 ("Zaman", 2010). So 893 books in 8 years is a big leap forward, http://www.tedaproject.gov.tr.

11 President of Calinos Holding Company Frrat Gülgen, which makes $80 \%$ of the total exports of Turkish dramas, states that increasing popularity of Prime Minister Erdogan, specifically after the "one minute incident" in Davos, facilitated their sales in the Middle East ("Milliyet", 2011). 
reached to 23,091,896 from 12,134,197. The increase in ratio in ten EU member countries, in the same period is only 53 per cent. ${ }^{12}$ The increase from other OECD countries is 172\%; from Commonwealth of Independent States is 237\%; from other Southeast Asian countries is 156\%; other West Asian countries 210\%; other African countries 255\% and other American countries 255\%. A selected sample that is shown below also tells us that ex-Soviet republics and Middle Eastern countries are occupying the first two ranks in the increase among the tourist that visits Turkey (Turkish Statistical Institute).

Table 2

Tourists visiting Turkey

\begin{tabular}{||l|r|r|r||}
\hline \hline Total & \multicolumn{1}{c|}{$\mathbf{2 0 0 3}$} & \multicolumn{1}{c|}{$\mathbf{2 0 0 9}$} & change $\mathbf{~}$ \\
\hline Ukraine & $12,134,197$ & $23,091,896$ & 90 \\
\hline Russia & 185,929 & 460,980 & 148 \\
\hline Georgia & $1,178,262$ & $2,065,588$ & 75 \\
\hline Azarbaijan & 148,488 & 974,111 & 556 \\
\hline Tunusia & 189,910 & 404,063 & 113 \\
\hline USA & 34,449 & 53,891 & 56 \\
\hline Canada & 213,699 & 614,025 & 187 \\
\hline Syria & 39,171 & 143,065 & 265 \\
\hline Iran & 134,126 & 457,099 & 241 \\
\hline Ýsrael & 375,496 & $1,291,592$ & 244 \\
\hline Japan & 236,643 & 252,041 & 7 \\
\hline Australia & 79,912 & 146,804 & 84 \\
\hline Country group's total & $4,863,326$ & $6,986,805$ & 144 \\
\hline EU10 & $6,365,603$ & $9,760,651$ & 53 \\
\hline \hline
\end{tabular}

Source: Turkish Statistical Institute (TUIK), http://www.tuik.gov.tr, 19.05.2013.

The change in number and qualities of travels of Turkish citizens also influences Turkey's Foreign policy interests and decisions. It creates awareness among the citizens about the world. This awareness and demand for more travel, when faced with visa barriers has its reflections at political level. The areas that were not within the sight of government are brought forward by travelling people, and visa became a political issue for the government to attract more sympathy and vote from the public. It can be also said that a kind of positive populism and nationalism developed out of visa issue.

Travel patterns of Turkish citizens, in terms of selected/decided destination countries, has been showing a gradual change. Turkish citizens have been travelling abroad more than ever. The total number of Turkish citizens travelling abroad was $3,516,885$

12 These ten EU member countries are Germany, Austria, Belgium, Denmark, France, Netherland, The UK, Sweden, Italy and Greece. 
by year 2003 . This number increased 62.6 per cent and reached to $5,717,079$ by year 2009. The increase on Turkish citizens travelling to EU15 has been realized as $40.9 \%$. This increase is 21.7 points less than the overall average increase. This increase reaches $115.1 \%$ in a selected sample of mostly visited non-EU countries. This is 52.5 point increase above the average.

Table 3

States visited by Turkish tourists

\begin{tabular}{||l|r|r|c||}
\hline \multicolumn{1}{|c|}{ States visited by Turkish citizens } & $\mathbf{2 0 0 3}$ & $\mathbf{2 0 0 9}$ & $\begin{array}{c}\text { \% change } \\
\text { (2009-2003) }\end{array}$ \\
\hline Total & $3,516,885$ & $5,717,079$ & 62.6 \\
\hline EU 15 & 885,898 & $1,248,499$ & 40.9 \\
\hline EU 27 & $1,635,381$ & $2,144,796$ & 31.1 \\
\hline EU27-EU15 & 749,483 & 896,297 & 19.6 \\
\hline Non-EU & $1,881,504$ & $3,572,283$ & 89.9 \\
\hline Selected countries* & $1,097,399$ & $2,360,920$ & 115.0 \\
\hline
\end{tabular}

* Azerbaijan, Georgia, Kazakhstan, Moldova, Uzbekistan, Russia, Belarus, Tajikistan, Turkmenistan, Ukraine, Israel, Syria, Jordan, Egypt, Bosnia Herzegovina, Macedonia, the United Arabic Emirates, Iraq, Iran, China, India, Afghanistan, Malaysia, USA, Albania, Libya.

Source: Turkish Statistical Institute (TUIK), http://www.tuik.gov.tr, 19.05.2013.

This change in Turkish citizens' visits abroad is mostly related to the visa regulations that destination countries apply. New Turkish bourgeoisie who have resources and curiosity about the external world wants to travel more for various reasons. When they face visa restrictions they change their route to countries which are relatively easy and cheap to visit. Travel programs on private and state owned TV channels which create curiosity about foreign destinations ${ }^{13}$ and recent visa removal agreements that the government made with several countries are also expected to be influential over peoples' travel decisions. ${ }^{14}$

\section{CHANGE IN THE DIRECT AND INDIRECT FOREIGN INVESTMENT IN TURKEY}

Turkey's economy having serious capital shortages have been running for foreign direct and indirect investment. For this end Turkey-Japan relations developed during

${ }^{13}$ Among these TV shows which create curiosity on Turkish people about the outside world Barış Manço's "7'den 70'e"; Mehmet Ali Birand's international news oriented "32.Gün"; Samanyolu TV's faith based mission oriented "Ayna"; Türksoy's Turkish speaking communities focused TV shows are important ones.

14 There was a boom on visits to Syria. However after the demonstrations and then civil conflict started and Turkey-Syrian relations deteriorated touristic visits shrunk and almost stopped. Even though Greece only removed visa for green passports, there is a visible increase on Turkish green passport holder citizens visits to this country. 
the 80s. The governments, in order to attract more investment, tried to develop good relations with countries which are considered potential investors. So attracting foreign direct investment and foreign indirect investment is important for governments and it has its projection over the foreign policy decisions and behaviours.

It is quite difficult to collect and analyse data regarding this field. The basic reason is that the money does not have a passport and can travel freely all around the world. After the big increase in the petroleum prices there has been a great fortune accumulation on the petroleum producing countries. It has been openly declared by Turkish government authorities that the government was running after this excess Money in the Gulf (Erdoğan, 2010; Wigglesworth, Strauss, 2010).

According to the Middle East Journal, Saudi Arabia, Kuwait, Qatar, United Arabic Emirates, Bahrain and Oman (GulfCooperation Council-GCC members) earned a total of more than USD 1.5 trillion from their exports in the five year period in between 2002-2006. Of this amount some USD 542 billion representing the capital funds entered global capital markets. So, the $G C C$ countries foreign assets reached to USD 1.6 trillion (The Middle East, 2007: 39).

The JDP has been trying to attract some of this money to Turkey. Even though there is not concrete evidence, the strength of Turkish economy to international financial crises and shocks would be partly related with the success of government to attract this money to Turkey. Even before the $J D P$ came to power, Turkish economies' foreign capital hunger was a well-known fact. Pre-JDP governments had been searching this money mostly in the European and US financial markets. During the Özal years Japan became a new and an alternative destination.

It was either from the European, or US market, most probably the Petro dollars of the Gulf countries had also been routed to Turkey through the European and American finance corporations with an additional profit margin for western finance corporations. There were ideological reasons and settled patterns which were directing Turkey's finance sector to those destinations. Together with the JDP, a new cadre which was ideologically not that much distant to Arab capital, which had been in contact with the Arab world due to religious solidarity or cultural closeness broke this pattern and started to work with Arab countries as well. This does not mean that they quit working with Europe and the US. The basic principle had been pragmatism next to ideological and cultural closeness in this period.

Due to these ideological framework changes at governmental level and changes at global economic level, including the new giant petro dollar surplus in the gulf, the nature of foreign direct investment to Turkey has been changing since 2005. The amount of foreign direct investment reached to USD 10 billion by a radical shift from previous years USD 2.9 billion by 2005. With this change Turkey's share in global total foreign direct investment reached to $1 \%$ from previous years' $0.4 \%$. After another important shift to $1.4 \%$ by 2006 , Turkey has kept its global share around $1 \%$ in foreign direct investments. By 2009, this share went down to $0.7 \%$ by USD 7.6 billion FDI. Due to the economic crises experienced by 2008 and 2009, this change does not say so much for the moment.

When these figures are analysed in detail it can be seen that there has been a change in the share of European countries on FDI. This share was $86.8 \%$ by 2004 . By 2005 , it 
reduced to $77.9 \%$. There has been a return in 2006 by $82.6 \%$. By 2007 there was a radical fall to $67.8 \%$. This ratio returned to 2004 level by 2009 with $84.9 \%$.

Table 4

Allocation of Foreign Direct Investment by Regions

\begin{tabular}{||l|c|c|c|c|c|c||}
\hline & $\mathbf{2 0 0 4}$ & $\mathbf{2 0 0 5}$ & $\mathbf{2 0 0 6}$ & $\mathbf{2 0 0 7}$ & $\mathbf{2 0 0 8}$ & $\mathbf{2 0 0 9}$ \\
\hline Europe (million USD) & 1,033 & 6,652 & 14,574 & 12,974 & 11,342 & 4,834 \\
\hline Share (\%) & 86.8 & 77.9 & 82.6 & 67.8 & 77.0 & 84.9 \\
\hline North America (million USD) & 97 & 114 & 969 & 4,223 & 886 & 271 \\
\hline Share (\%) & 8.2 & 1.3 & 5.5 & 22.1 & 6.0 & 4.8 \\
\hline Asia/Near and Middle East (million USD) & 54 & 1,678 & 1,910 & 608 & 2,199 & 262 \\
\hline Share (\%) & 4.5 & 19.7 & 10.8 & 3.2 & 14.9 & 4.6 \\
\hline Asia/Other (million USD) & 6 & 78 & 17 & 797 & 162 & 299 \\
\hline Share (\%) & 0.5 & 0.9 & 0.1 & 4.2 & 1.1 & 5.3 \\
\hline Other Regions (million USD) & - & 13 & 169 & 535 & 144 & 28 \\
\hline Share (\%) & 0.0 & 0.2 & 1.0 & 2.8 & 1.0 & 0.5 \\
\hline Total (million USD) & 1,190 & 8,535 & 17,639 & 19,137 & 14,733 & 5,694 \\
\hline
\end{tabular}

* Central Bank of Turkey

Source: Foreign Direct Investment Evaluation Report (2009), YASED.

In these periods, investors of Asian, Near and Middle Eastern countries showed a visible and measurable but not that much stable/regular interest to Turkish economy in terms of direct foreign investment. These countries' share was around $4.5 \%$ by 2004 . By 2005 with a radical shift upward, it reached to $19.7 \%$ which was the highest level during the last decade. Their share fell down to $10.8 \%$ by 2006 and with a contraction to $3.2 \%$ by 2007 . There has been a return to $14.9 \%$ by 2008 and another contraction to $4.6 \%$ by 2009 which was an expected outcome of the economic crises (Foreign, 2009).

Turkey's general performance to attract foreign direct investment has increased since 2005 and Middle and Near Eastern countries had increased their share in the total FDI figures even though this was not stable and steady process. Arab countries in this period heavily invested on telecommunication, finance, real-estate and health sectors. Only the appropriation of Turk Telekom by Oger Telecom amounted USD 6.5 billion. Appropriation of Adabank by Kuwaiti origin company The International Investor amounted USD 45.1 million; appropriation of $M N G$ bank by Dubai Islamic Bank by USD 160 million are some of the examples of big transactions in this period. There have been also Arab capital investments in Istanbul Stock Exchanges. According to Yavuz Semerci (2007), the speculated amount of Gulf countries originated investment in Istanbul Stock Exchanges is about USD 5 billion. ${ }^{15}$

Even though it is difficult to determine the exact source of foreign investment increase, it can be said that there is an increase on the share of Middle and Near Eastern

15 It should be noted that it is nearly impossible to determine the source of foreign capital which is funded in İstanbul Stock Exchanges as it is quite difficult to trace the movement of money in the world. 
Capital in Turkey. Simon Williams, the Chief Economist at $H S B C$, explains the reason of this interest to Turkish economy by Gulf countries, in quite an economic/efficient way. "It is an obvious and natural relationship [...] The Gulf has capital and Turkey has capital needs. They are close geographically, there are cultural and religious similarities, and Turkey is a good economic story right now". ${ }^{16}$ When this "natural" environment, combined with the efforts of Turkish government to attract FDI with signed and worked Free Trade Agreements; and Turk-Arab Economic Forums, the fifth of which was made by June 2010, the outcome has been an increase in the share of Arab countries in FDIs. There have also been references to Turkey's EU venue as the reason of this increasing Arab capital interest to Turkey. EU venue makes Turkey more predictable and provides capital owners a vision for the future of the country (İdiz, 2010).

When analysing the flow of foreign capital to Turkey the foreign capital phobia in this country should also be analysed. There is a discrimination against Arab capital that rises from non-governmental groups and becomes visible at national media. This discrimination also makes the Arab capital a bit hesitant on their investment decisions to Turkey (Dikbaş, 2008). Arab capital phobia is mainly visible among the secular nationalist circles which have some concerns about the intentions of the Arab capital. This discrimination or capital phobia is not only limited to Arab capital. The intentions of any Jewish capital are also subject to scrutiny but this time mainly by religious and nationalist political groups. $^{17}$

It should also be noted that that during the last 10-20 years, the intentions of European, US, Japanese or Russian capital have not been questioned except some general ideological objections which has been raised by some limited nationalist and/or socialist political groups.

This fact provides non-Arab and non-Jewish capital some relative advantages in Turkey. For the moment it can be said that Turkey due to the increasing performance of her economy and her big growth rate has been developing some capabilities to attract some of the Gulf capital which does not have a political power to back/protect her investments abroad. JDP government seems as if providing the guarantees that the Gulf capital needed due to previously established ideological, political and cultural ties.

The Gulf capital has been directly going to countries which provide a high degree of shelter and guarantees for them. The existing tendency of free and independent movement of this capital without the guidance and protection of western finance moguls would be something threatening the hegemonic monopoly of European and western capital centres for the mid-term future. However for the moment the west seems as if repossessed her oligopolistic share in Turkish FDI market.

This pressure to the current structure of the system can also be read that Turkey would rise as a new finance centre for the Gulf capital through which Gulf capital own-

16 Quoted by Robin Wigglesworth and Delphine Strauss (2010).

17 Galataport project would be an example of this incident. Next to the rightful objections of some writers about the content of the project which would destruct the historical panorama of Istanbul, there were some opponents who had an anti-Jewish attitude as well (Sabah, 2005) even Prime Minister Erdoğan criticised the ones who declare their objection to Galataport project as anti-Jewish (Başbakan, 2005). 
ers can enjoy a safe shelter in which they would also have a political impact over a strong government with which they could easily communicate in return for a continues capital supply from which Turkish governments could gain a strength vis-à-vis the western financial centres speculative strikes.

$$
\text { *** }
$$

There has been a change pattern in Turkish foreign policy since the 1980s. Economic liberalism, democratization and the end of the Cold War were the factors which led to this change. This occurred mostly due to structural reasons. JDP governments' contribution to the change was, mainly related to rhetorical and ideological flavor that was visible in Davtuoğu's foreign policy and power formulations.

JDP as a populist political party responded to the undercurrent and tried to re-position Turkish state to float in harmony with these. When $J D P$ went beyond the domestic and international structural limits due to her narrow ideological preferences as she did during the Syrian Civil War, these constraints pulled her down to stay within the limits.

Turkish foreign policy has been fluctuating since the beginning of the second term of the $J D P$ government. During 2009 and 2010 period it has been boldly claimed that there was a diversion from the traditional western oriented stance of the Turkish foreign policy. Starting with the Arab Spring and during the late stages of Egyptian Revolution and Libyan Revolution (especially after the evacuation of 25,000 Turkish migrant workers from this country), Turkey, reconsidered her foreign policy and came closer to the US and the West, again. When demonstrations began and Syrian government aggressively suppressed opposition groups, Turkey's side without any doubt was clear and together with the west. Government openly criticized Syrian government with which she had unbelievably genuine looking relations just a while ago, for her brutal reactions against her own citizens and declared her support for the demonstrators. Turkey's bilateral relations with Iran also radically changed in this period. After Turkey granted permission to the launch of NATO commanded anti-missile system in Malatya, Turkey-Iran relations deteriorated.

Sectarian differences and competition is frequently shown as the main reason of recent change in Turkey-Iran relations and Turkey's attitude change about Syria. This argument does not tell what triggered this sectarian conflict and shaken the already existing balance between Iran, Syria and Turkey. The change, at least partially, seems as if linked with the US's evacuation of Iraq. For Turkey, Iran's attempt to fill the existing power vacuum in Iraq and governments perceived encirclement of the country with a Shiite crescent, for Iran being excluded from Iraqi politics and following a regime change in Syria, perception of being encircled with a Sunni crescent seems as if the main fears and concerns dominating the mutual distrust and confrontational foreign policy positions of the parties. One should also mention that this mutual distrust and mutually feeding threat perceptions are partially influenced by the predominant view of the US and Western authorities and scholars that see Iraq and Syria as states which are mainly composed of people from different sects and denominations. Once this view dominates a polity, it is unavoidable for smaller powers to take their positions accordingly and see the "reality" from the perspective of the hegemonic power. 
Even though Turkish government had developed good relations with the authoritarian leaders of the Middle Eastern countries, including Iran, Syria and Libya in the recent past, after seeing that these leaders would not stand out against political opposition that demand more liberty, it became impossible for $J D P$ government to continue her support to those leaders. Being accused as non-democratic by supporting those authoritarian leaders was also a risk that $J D P$ would not like to take. There are very big systemic constraints over the region and it is quite difficult for Turkish government to resist the pressures of global hegemon, the US and her western allies. The attractiveness of filling the power vacuum after the US withdrawal from Iraq and having some advantages on her struggle against to $P K K$ are pull factors that could be listed as reasons of change here.

Taking into consideration the transitional nature of all these regional developments, it could be claimed that Turkish foreign policy would be normalized after the settlement of these crises. Following the establishment of a relatively stable international regime in the region (it is not necessary to see dearly regimes around), one could expect that Turkish foreign policy would try to return to the line that was observed during the second $J D P$ government period. In such circumstances, Turkey would act again, as mainly a trading state which develops cultural and political relations with her neighbours by avoiding confrontational politics. Even a change in the government composition would not lead to a big diversion but some rhetorical changes. This expected tendency is mainly related to the economic and social changes that Turkey has been experiencing. Agents of the economy are more aggressive and keep looking for new markets, Turkish economy has been integrated with the capitalist trading networks in the world, there are more and more investments done by the international capital. Turkey's population has developed an interest in the world surrounding them. Turkish people want to travel more and the country is visited by more people from a wide spectrum of destinations. Turkey has been receiving migrants from Asia and Africa and you can see a Turkish Diaspora Community all around the world. All these factors force and motivate political parties and governments to develop a more liberal and out looking foreign policy instead of a confrontational and inward looking one.

\section{Bibliography}

AB'den Gümrük Birliği golü (EU's Customs Union Score on Turkey) (2010), “Cumhuriyet”, 21 September.

Akgun M. (2009), Eksen kaymast var mı (Is there a shift on the axis?), "Referans", 16 November.

Akgün M. et al (2010), Ortadoğu'da Türkiye Algısı 2010 (Turkey perception of the Middle East 2010), Istanbul.

Ak Partide Davutoğlu Tartışması (2010), "Milliyet”, http://www.milliyet.com.tr/ak-parti-de-davutoglu-tartismasi/siyaset/haberdetay/05.12.2010/1322324/default.htm, 19.05.2011.

Aras B. (2009), Davutoğlu Era in Turkish Foreign Policy, "Policy Brief” No. 32, Ankara.

Ayverdi S. (1975-76), Türk tarihinde Osmanlı asırlarl (Ottoman Centuries in Turkish History), Istanbul.

Başbakan: Yahudi düşmanlı̆̆ yapmayın (Prime Minister: Do not be anti-Jewish) (2005), "Radikal", http://www.radikal.com.tr/haber.php?haberno=165784, 19.05.2013. 
Birand M. A. (2010), Gerçek eksen kayması böyle olur ... (Real axis shift happens like this...), "Posta", 16 June.

Buttler D. (2009), Turkey's Brad Pitt'stirs wide Arab interest, "Reuters", 10 March.

Candar C. (2000), Türkiye'nin yönü neresi? (Where does Turkey head to?), "Hürriyet”, 21 October.

Davutoğlu A. (2010), Stratejik Derinlik (Strategic Depth), İstanbul.

Dikbaş K. (2008), Sermayenin Rengi (Colour of Capital), “Zaman”, 02 May.

Eralp Y. (2010), Eksen Kaymass (Axis shift), “CNNTurk.com”, 09 July.

Erdoğan T. (2010), AK Parti Grup Toplantısl, http://www.akparti.org.tr/ak-parti-grup-toplantisi-_7065.html, 08.09.2010.

Foreign Direct Investment Evaluation Report (2009), YASED, February.

Friedman Th. (2010), Letter from Istanbul, "New York Times", June 15.

İdiz S. (2010), Arapların Türkiye Illgisi Nereden Geliyor? (Where does the Arabs' interest on Turkey come from?), "Milliyet", 26 June.

Inbar E. (2011), Turkey's Changing Foreign Policy and Its International Ramifications, "Orbis" Vol. 55, No. 1.

Kaplan M. (1967), Nesillerin Ruhu (The Spirit of Generations), Istanbul.

Kemal Y. (1975), Tarih Musahabeleri (History Conversations), Istanbul.

Kirişçi K. (2009), Transformation of Turkish Foreign Policy: The Rise of the Trading State, "New Perspectives on Turkey" No. 40.

Kültür sanatta dış ticaret fazlası 300 milyon dollar (Foreign trade excess on culture and art is 300 million dollars) (2010), “Zaman", http://www.zaman.com.tr/ekonomi_kultur-sanatta-dis-ticaret-fazlasi-300-milyon-dolar_969434.html, 19.05.2013.

Moisi D. (2009), Who lost Turkey?, http://www.project-syndicate.org, 19.05.2013.

Oğuzlu T. (2008), Middle Easternization of Turkey's Foreign Policy: Does Turkey Dissociate from the west, "Turkish Studies" Vol. 9, No. 1.

Öztuna Y. (1998), Osmanlı Devleti tarihi (History of Ottoman State), Ankara.

Şahin M. (2011), Islam, Ottoman Legacy and Politics in Turkey: An Axis Shift?, "The Washington Review of Turkish and Eurasian Affairs", January, http://www.thewashingtonreview.org/articles/islam-ottoman-legacy-and-politics-in-turkey-an-axis-shift.html, 19.05.2013.

Semerci Y. (2007), Körfez Sermayesi Türkiye’ye Aklyor (Gulf capital flows into Turkey), http://ekonomi.haber7.com/ekonomi/haber/256699-korfez-sermayesi-turkiyeye-akiyor, 19.05.2013.

Steyn M. (2010), Today's Young Turks revere Islam, not NATO, "Washington Times", June 4.

The Middle East (2007), "Gulf Investors Focus on Arab and African Neighbors", August/September.

Turan O. (1969), Türk cihan hakimiyeti mefkuresi tarihi (History of Turkish Global Hegemony Ideal), Istanbul.

Türk dizilerinin yurt dişı rekoru (Record of Turkish series abroad) (2011), "Milliyet", http://www.milliyet.com.tr/turk-dizilerinin-yurt-disi-rekoru/ekonomi/sondakika/15.01.2011/ 1339711/default.htm, 19.05.2013.

Turkish Statistical Institute (TUIK), http://www.tuik.gov.tr.

Wigglesworth R., Strauss D. (2010), Turkey focuses on Gulf two-way ties, "Financial Times", 21 June.

\section{ABSTRACT}

There has been a wide debate in Turkey about the changing orientations, directions and conducts of Turkish Foreign Policy (TFP) during the JDP governments. This article examines the JDP era with reference to some structural changes such as change in Turkey's foreign trade pro- 
file, change on Turkish citizens travel destinations and changing composition of incoming tourists to Turkey, change in Turkey's culture industry and exportation of Turkey's culture products abroad, change in foreign direct investments to Turkey. The article also examines the ideational parameters of JDP's foreign policy based on the writings and speeches of Ahmet Davutoğlu as intellectual architect and then as JDP government's Minister of Foreign Affairs fully in charge of design and conduct of foreign policy. The article basically concludes that the change on TFP has been based on some deeper changes in Turkey at economic, political and sociological level since 1983. These domestic and international structured changes, interpreted by Davutoğlu in a particular way led to the change and the change debate on Turkish Foreign Policy.

\section{KONTYNUACJA I ZMIANA W TURECKIEJ POLITYCE ZAGRANICZNEJ W OKRESIE RZĄDÓW JDP}

\section{STRESZCZENIE}

Od chwili przejęcia władzy w Turcji przez partię $J D P$, prowadzona jest debata na temat zmiany kierunków i realizacji polityki zagranicznej państwa. W artykule analizie poddano okres rządów $J D P$ z uwzględnieniem takich zmian strukturalnych jak przeobrażenie profilu handlu zagranicznego Turcji, turystyki wyjazdowej i przyjazdowej, a także zmian w tureckim 'przemyśle kultury'. Analizie poddano również założenia polityki zagranicznej partii JDP, prezentowane przez Ahmeta Davutoglu - byłego ministra spraw zagranicznych, odpowiedzialnego za określenie i prowadzenie zmian w polityce zagranicznej Turcji. 
